OPEN ACCESS

Edited by:

Simon Allen,

Universität Zürich, Switzerland

Reviewed by:

Govindan Krishnan, Indian Council of Agricultural

Research (ICAR), India

Zoe Courville,

Cold Regions Research

and Engineering Laboratory,

United States

*Correspondence:

Anupam Sharma

anupam110367@gmail.com

Specialty section:

This article was submitted to Interdisciplinary Climate Studies,

a section of the journal

Frontiers in Earth Science

Received: 02 April 2018

Accepted: 20 September 2018

Published: 09 October 2018

Citation:

Sharma A and Phartiyal B (2018)

Late Quaternary Palaeoclimate and Contemporary Moisture Source to Extreme NW India: A Review on

Present Understanding and Future Perspectives. Front. Earth Sci. 6:150.

doi: 10.3389/feart.2018.00150

\section{Late Quaternary Palaeoclimate and Contemporary Moisture Source to Extreme NW India: A Review on Present Understanding and Future Perspectives}

\author{
Anupam Sharma* and Binita Phartiyal \\ Geochemistry, Birbal Sahni Institute of Palaeosciences, Lucknow, India
}

The trans-Himalayan region of NW India including the western part of Tibet, Karakoram, and Hindukush range host thousands of glaciers ensuring perennial freshwater supply to the Indian subcontinent and supports a large fraction of the global population. The peculiar physiography not only limits the entry of water enriched Indian Summer Monsoon winds to this region but also give passage to dry winds of barren desert of the Taklamakan, the Aksai Chin, and western Tibet, to qualify it as a cold desert. The Himalayan Orogen linked structural elements and the Quaternary glacial, and interglacial phases define the geomorphological setup of the region, which subsequently modified by the fluvial-lacustrine-aeolian processes. Over the years, our understanding in drawing climatic inferences from the sedimentary archives has improved significantly but the discrepancy in chronology, among and within different dating techniques, poses a serious challenge and therefore requires more work to address the issues. Similarly, till recently, it was argued that the major source of moisture to the Ladakh region is contributed from the Mediterranean Sea because the region falls under the rain shadow zone for the water-laden Indian summer monsoon winds. Our recent water isotopic study of upper Indus River Basin, however, emphasized that Indian summer monsoon source is also an equally important supplier. The present review highlights that the disturbed chronology and inadequate data support on moisture sources are two gap areas for further research. Keywords: sedimentary archives, climate proxy records, ${ }^{14} \mathrm{C}$ radiometric dating, $\mathrm{OSL}$ and ${ }^{10} \mathrm{Be}$ dating, monsoon,
westerlies

\section{INTRODUCTION}

The trans-Himalayan region of NW India bears immense significance, primarily because it hosts thousands of glaciers, which ensures perennial fresh water supply to the Indian subcontinent and in turn supporting a large fraction of the global population. Secondly, it is the only region that experiences semi-arid to arid cold desert climate, whereas the rest of the subcontinent falls under the tropical to subtropical warm and humid monsoon climate and therefore provides an opportunity to understand different phenomenon associated with the lower and upper atmospheric 
circulations. Additionally, it serves as an open laboratory for understanding the geological processes related to the Himalayan orogeny (Henderson et al., 2010; Singh et al., 2015). The associated tectonics also has a profound impact on weathering and erosional processes having wider implications toward modulating the global climate and needs to be studied more systematically to meet the challenges of global climate change (Ruddiman and Kutzbach, 1989; Raymo and Ruddiman, 1992; Singh et al., 2005).

Ever since the northward-moving Indian plate struck with the relatively stable Eurasian plate, this gives birth to the mighty Himalayas (Molnar and Tapponnier, 1975; Steck et al., 1993; Yin, 2006). In the process, the climate of the Indian subcontinent keeps modulating with time (Edmond and Huh, 1997; Guo et al., 2002; Clift et al., 2008). The Himalayas is the youngest mountain belt of the world, and because of significant height, it hosts the largest glacier mass outside the Polar Regions. Therefore, the Himalaya is often considered as the third pole as well as the water tower of the Indian subcontinent (Viviroli et al., 2007; Immerzeel et al., 2010; Bookhagen, 2012; Mukherji et al., 2015). The role of Himalaya is not only important in determining the physiographic distinctions of the Indian landmass where it acts as a barrier for the northward-moving moisture-laden monsoon winds during the summer season but also restricts the entry of icy winds coming from the north during the winter season (Mayewski et al., 1980; Goudie et al., 1984; Searle, 1991).

The extreme north-western part of India, also known as trans-Himalaya, falls under the rain-shadow zone for monsoon clouds and therefore experiences cold desert climate (Figure 1) (Pant et al., 2005; Phartiyal et al., 2005, 2018). Our own, as well as several other authors, work suggest that the major atmospheric systems responsible for bringing moisture to the trans-Himalaya are the Indian summer monsoon (ISM) and the westerlies (Ramesh and Sarin, 1992; Pande et al., 2000; Karim and Veizer, 2000, 2002; Hren et al., 2009; Ahmad et al., 2012; Halder et al., 2015; Rai et al., 2016; Sharma et al., 2017). The InterTropical Convergence Zone (ITCZ) governs the spatial extent and the strength of these two systems. Besides, there are several other forcing factors, which includes solar insolation and surface albedo (linked to sunspot activity), the North Atlantic Oscillation (NAO), Atlantic sea-surface temperatures (SST), Bond cycles, that also cause short-term oscillations in the monsoon intensity (e.g., Gupta et al., 2003; Lang and Barros, 2004; Sinha et al., 2006).

Monsoon is a very important atmospheric phenomenon of the Afro-Asian region and also a very important component of the global climate (Kutzbach and Otto-Bliesner, 1982; Kutzbach et al., 1993; World Clim Res Programme [WCRP], 2009; Zhisheng et al., 2015; Sharma et al., 2017). Therefore, directly or indirectly, it attracted several workers to study the palaeoclimatic history of the trans-Himalaya (Bhattacharyya, 1989; Sekar et al., 1994; Gasse et al., 1996; Brown et al., 2002; Shukla et al., 2002; Demske et al., 2009; Dortch et al., 2010, 2013; Wünnemann et al., 2010; Phartiyal et al., 2013, 2015; Blöthe et al., 2014; Kumar et al., 2017; Lal et al., 2018). Studies based on sedimentary archives, which include glacial (Fort, 1983; Dainelli, 1922; Kuhle, 1998; Owen et al., 2006; Achenbach, 2010), fluvial (Sharma et al., 1998; Shi et al., 2001; Dortch et al., 2011; Sangode et al., 2011; Scherler et al., 2014; Nag and Phartiyal, 2015), lacustrine (Gasse et al., 1996; Shi et al., 2001; Wünnemann et al., 2010; Phartiyal et al., 2013, 2015) and aeolian (Kumar et al., 2017) deposits, significant work has been carried out. Climate proxies that include biotic proxies mainly pollen-spore based studies (Bhattacharyya, 1989; Demske et al., 2009; Wünnemann et al., 2010) and various abiotic proxies (Fort et al., 1989; Gasse and Van Campo, 1994; Fontes et al., 1996; Bhushan et al., 2018) were employed to retrieve palaeoclimatic signals preserved in the sediments. Besides, several chronological techniques such as conventional and accelerated mass spectrometry (AMS) carbon radiometric dating (Phartiyal et al., 2005, 2013), optical luminescence dating (OSL) (Dortch et al., 2010, 2013; Blöthe et al., 2014) and cosmogenic radionuclide dating (Brown et al., 2002; Dortch et al., 2010, 2013; Blöthe et al., 2014) have also been applied. Based on the works mentioned above, a fairly good understanding over the palaeoclimate of the mid-late Quaternary, more so the period extending from Last Glacial Maxima (LGM) to recent, is developed for the NW trans-Himalayan India.

In the present work, we are revisiting to some of our work as well as reviewing the works carried out by other workers highlighting the discrepancy observed in chronology, which has serious implications toward the palaeoclimate record of the NW India (primarily the Ladakh and Spiti regions). Similarly, we also discuss the quantitative estimation of contributions from different moisture sources to this region.

\section{STUDY AREA}

We are studying the geomorphological signatures and concentrating mainly on the lacustrine and fluvial sediments of the Ladakh and the Spiti regions of the NW Himalaya (Figure 1). The Tethyan sedimentary zone (TSZ) is the region between Main Central Thrust (MCT) and the Indus Suture Zone (ISZ), and further north is the trans-Himalaya (Figure 1A). The Ladakh Batholith, the Zanskar, and the Karakoram are the major mountain ranges in the area, and the Indus with its major tributary rivers, e.g., Zanskar and Shyok flow within these ranges. The Ladakh and the Spiti regions display characteristic geomorphology that is largely governed by the reworking and redistribution of Quaternary glacial deposits along with frost-shattered rocks draping the hills through stream runoff and mass movement (more on geomorphology is discussed in a later section). Sedimentary archives lying all along the Indus and its tributary rivers such as Shyok-Nubra, Tangtse and Zanskar in Ladakh (Phartiyal et al., 2005, 2013, 2018; Phartiyal and Sharma, 2009; Nag and Phartiyal, 2015) and along the entire stretch of the Spiti River (Phartiyal et al., 2009a,b, 2005; Srivastava et al., 2013) have been mapped and studied for their palaeoclimatic implications.

Similarly, the isotopic study of the main Indus, tributaries and first-second order streams water have also been carried out for ascertaining the source of the moisture to this region (Sharma et al., 2017). Similar study over the isotopic composition of the Spiti river water is in progress, and this would help us to compare as well as generalize the results over contributions received from 


\section{A}

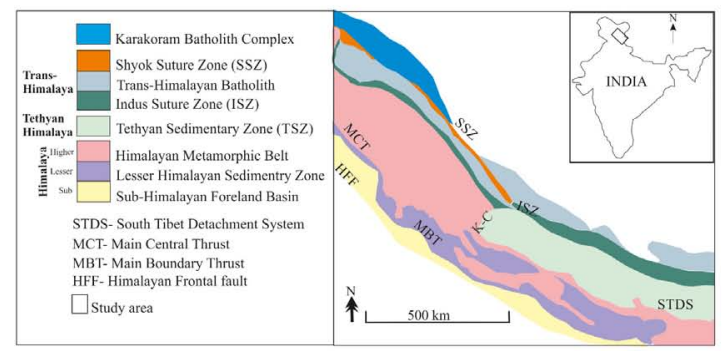

$B^{-6}$

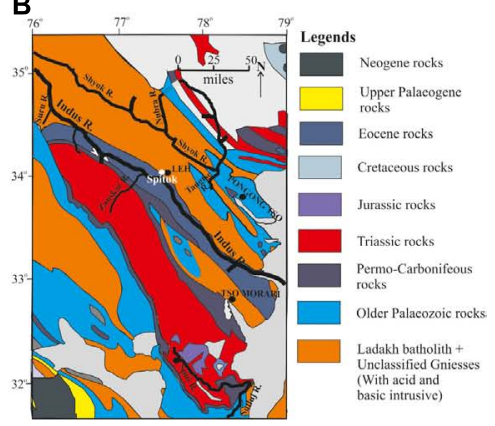

FIGURE 1 | (A) Map showing major mountain ranges and rivers of the NW India, and (B) Geological map of the Ladakh and Spiti valley of NW Himalaya including major rivers (please see text for lithological details). The figure also shows the Spituk site, situated near Leh City (solid white and black color circles, respectively), to highlight the discrepancy in the chronology under different dating techniques.

different moisture sources. To have a comprehensive idea of the study area, including the climate, geomorphology, and geology, these are discussed briefly in the following subsections.

\section{Climate}

Both Ladakh as well as the Spiti valley are located in the NW Himalaya at an altitude of $>3000 \mathrm{~m}$ above sea level (asl) and experience arid to semi-arid continental climate (Schmidt and Nüsser, 2017). The region remains under snow cover for 3-4 months (November to February); however, experiences prolonged winters extending from October to May. The average annual rainfall in the area varies from $<150$ to $\sim 40 \mathrm{~mm}$ from west to east (Blöthe et al., 2014). The vegetation is sparse and scanty restricted to river valleys only (Phartiyal et al., 2005). Due to high altitude, the intensity of solar radiation is significant resulting in large diurnal temperature variation. Overall, the cold and arid environment, $>5000 \mathrm{~m}$ relief, lack of vegetation (responsible for lower oxygen levels), rarefied atmosphere, large variation in seasonal temperature (varying from $-20^{\circ} \mathrm{C}$ in winter to $35^{\circ} \mathrm{C}$ in summer), and extremely low rainfall, all these attributes qualify to make Ladakh and Spiti regions a high altitude cold desert.

\section{Geomorphology}

The Ladakh and the Spiti are the highest altitude regions of India. Two sets of geological processes govern the overall geomorphological evolution of these regions: (1) Continentalscale geological processes, which include the collision of the Indian plate with Eurasian plate resulting into the closer of the Tethys Sea. The collision not only responsible for the birth of Himalayas but also the major force behind other geological features such as thrust belts, suture zones, nappes, volcanic arc (Molnar and Tapponnier, 1975; Klootwijk et al., 1985; Steck et al., 1993; Yin, 2006). All these have primarily provided the basic framework for the landscape evolution and (2) Regional/local scale geological processes in which the role of climate and tectonics is significant wherein the glacial (Figures 2a-d), fluvial (Figures 2e,f), lacustrine (Figures 2g-k), and aeolian (Figures 21,m) processes (Shukla et al., 2002; Dortch et al., 2013; Blöthe et al., 2014; Nag and Phartiyal, 2015; Kumar et al.,
2017) are important agencies of landscape evolution. Among these all, glaciers are the most effective agent because of their enormous mass and volume and can alter the existing, and in some cases completely new set of the landscape has been formed (Koppes and Montgomery, 2009; Bennett and Glasser, 2011). Other agencies, i.e., fluvial, lacustrine and aeolian bring changes at relatively smaller levels, however, govern the earth surface expressions in the form of various landforms such as U/V shape valleys, moraines and outwash plains, fluvial including strath terraces, aeolian landforms represented by dunes and sand ramps, and lakes and their deposits distributed all along the large rivers and so on (Figure 2).

The large difference in diurnal temperature facilitates intense frost action (physical/mechanical weathering) responsible for abundant supply of unconsolidated sediments, which are blanketing the mountain ranges and forming debris cones and piles in the valleys (Figures 2a,e,h) (Phartiyal et al., 2013; Srivastava et al., 2013; Kumar et al., 2017). Daming of major rivers that are believed to be an outcome of glacier retreat followed by a tectono-climatic activity (Fort et al., 1989; Phartiyal et al., 2005), has a profound impact on the geomorphology that is easily evident in the region. Among several types, the lake sediments are the most characteristic feature in the entire Ladakh and Spiti regions. Mass movement activity also supported the formation of complex diamicton depositional landforms (Owen and Derbyshire, 1989; Owen and Sharma, 1998). At higher altitudes 'U'-shaped cirque glaciers are present (Holmes, 1993) having periglacial environments (Fort, 1983), however, in lower regions, the valleys are ' $\mathrm{V}$ '-shaped with mean slopes of $25-30^{\circ}$ (Jamieson et al., 2004). The slopes are cut by gulleys helping debris and snowmelt-runoff and responsible for alluvial fans formation in the river valleys. The altitude, slope, and drainage distribution pattern adequately support the river channels steep bedrock reaches that transform to low angle braided alluvial landforms at relatively plainer areas (Figure 3). The drainage also shows that how in mere $\sim 400 \mathrm{~km}$ stretch the river Indus attained 7 th stream order (Figure 3). Besides, the evidence of various glaciation stages can also be noticed at Leh and its close vicinity, e.g., at Phyang, Tharu, and Basgo (Fort, 1983). All these agencies, mentioned above, with associated processes individually as well 

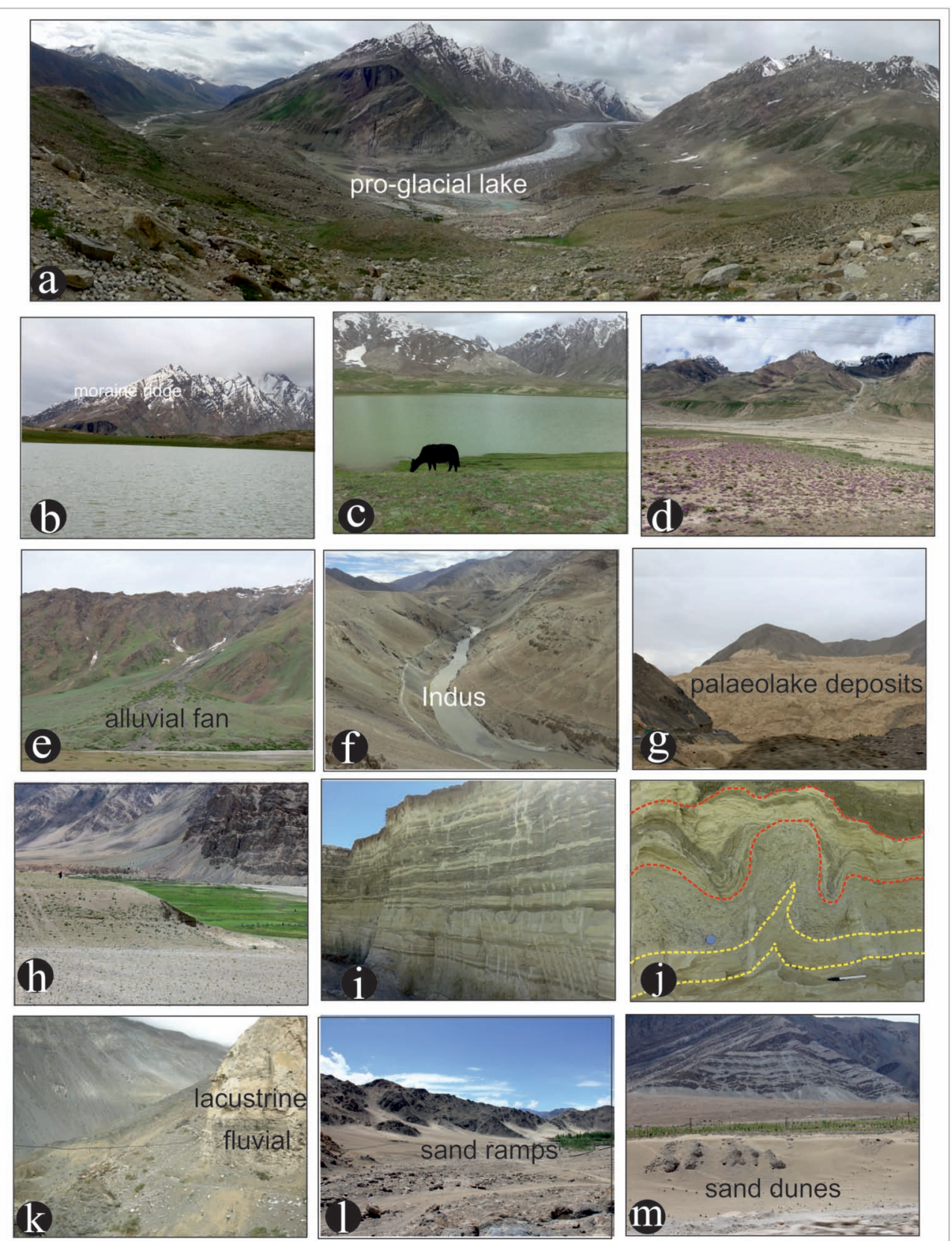

FIGURE 2 | Field photographs are showing the geomorphological features and overall landscape of the Ladakh and Spiti regions of NW Himalaya. (a) A Synoptic view of the Zanskar valley, a typical valley glacier (Photograph was taken from Penzi La), showing the Drang- Drung glacier. The curvilinear, recessional latero-frontal moraines present in front of the glacier snout have been dated to $4.8 \pm 0.4 \mathrm{ka}$ (Ali et al., 2018). The broad U shaped Zanskar valley is a manifestation of glacial erosion in the past. (b,c) Field photographs taken at Penzi-La (La = Pass; $4400 \mathrm{~m}$ asl) showing some recessional moraines and a high altitude lake supported by glacial meltwater. (d) At Padum village, the Zanskar valley has preserved the traces of right lateral moraine corresponding to the oldest stage of glaciation (stratigraphically). The meltwater stream coming from the tributary valleys have cut across this moraine and form the fans in the trunk valley. Younger moraines also seen along the tributary glacier valleys. (e) A huge alluvial fan emanating from the left slope and extending into the Zanskar valley. (f) Narrow gorge along the Indus River between Leh and Nimu in Ladakh. (g) Synoptic view of the Lamayuru palaeolake deposits in the Ladakh region. (h) Field photograph taken along the Zanskar valley (downstream of Padum) showing that the vegetation is restricted to the river valley, however, mountains are almost barren and blanketed by the weathered rock material, a very common freeze and thaw process responsible for breaking (physically/mechanically) the rocks into finer detritus. (i) One among many, fluvio-lacustrine deposit present near the confluence of Doda and Tsarp rivers near Padum. Such deposits are a direct manifestation and evidence of river impounding. The relict lake deposits also seen at many places along the Zanskar valley. (j) Close-up of the relict lake sequence showing well developed Synsedimentary/seismic deformation (shown by yellow dotted lines) and ice wedges (shown in red dotted lines). (k) A well-preserved relict lake section showing a sharp contact between fluvial and lacustrine facies near the Nako Village (Spiti Valley) and samples were collected for multiproxy studies. The lake section is around $100 \mathrm{~m}$ thick, and we have collected 9 OSL samples for dating the section and 660 samples for palaeoclimatic reconstruction; and (I,m) Field photograph showing sand accumulation by the dry winds near Leh. 


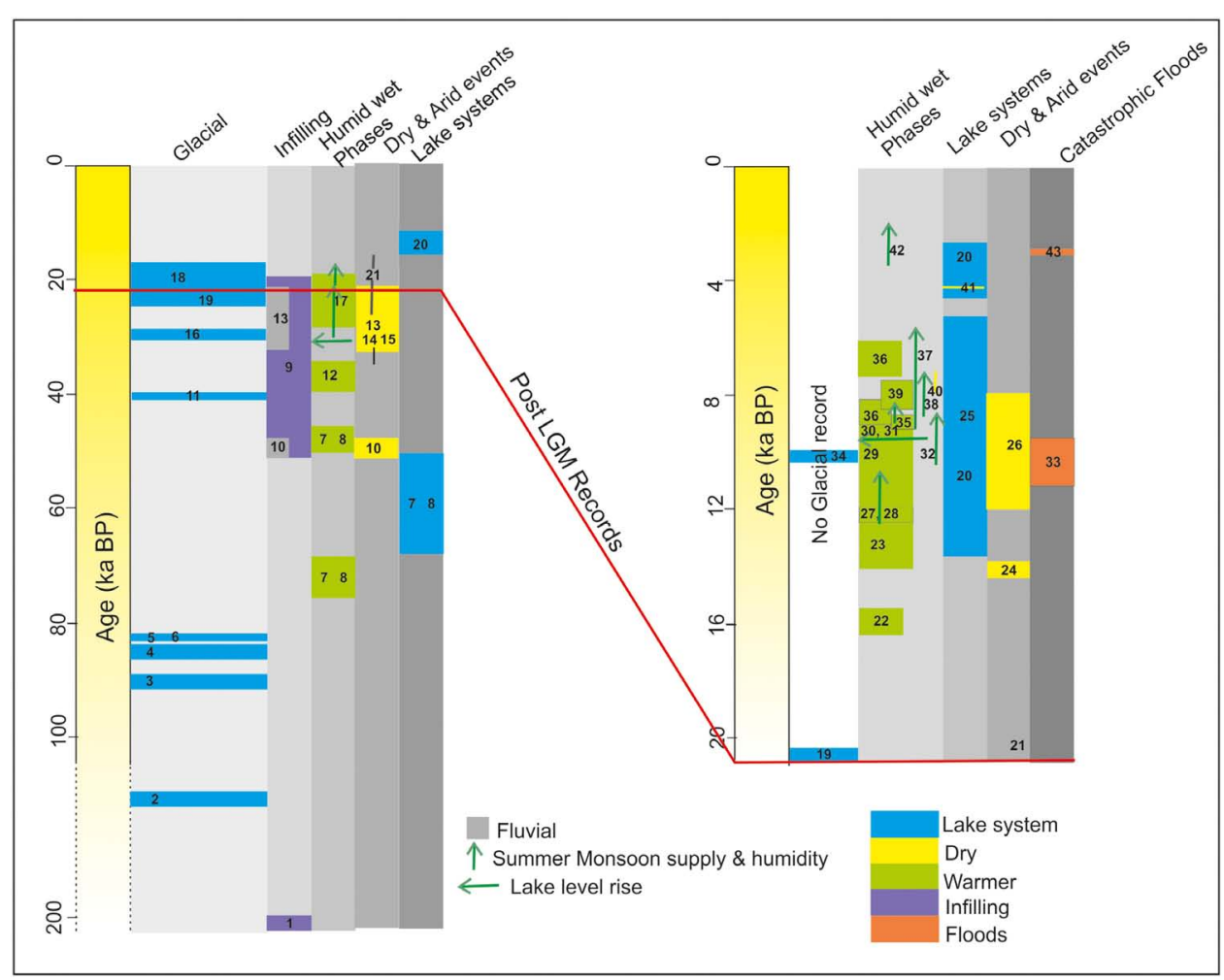

FIGURE 3 | Summary diagram showing different climatic regimes based on Table $\mathbf{1}$ in chronological order. The numbers shown in the diagram are taken from Table 1 as reference numbers to show the study referred, and the proxy used to infer the climatic regime as well as the dating technique applied by the respective authors. The vertical and horizontal arrows are used to show an increase in monsoon supply and lake level rise, respectively. The length of the different color boxes is indicative of the time duration to which the climate was in a particular mode, respectively.

as jointly, have governed the geomorphological evolution, mainly during the Quaternary period in this region.

\section{Geology}

The geology of the study area is highly complex as it marks the boundary between the relatively stable Eurasian plate and the northward subducting Indian plate (Searle et al., 1990; Henderson et al., 2010). The Indus River largely follows the ISZ; however, at places, it cuts the Ladakh Batholith, which represents the trans-Himalayan granodioritic belt of subduction-related intrusions (Figures 1A,B) (Fuchs, 1981; Garzanti and Van Haver, 1988). The major lithologies of the Ladakh region are tonalitic to granodioritic intrusives with mafic enclaves. However, the Indus basin sedimentary rocks represent forearc-basin sediments (Henderson et al., 2010; Singh et al., 2015). Further south of ISZ and toward the continental margin of India, the Neoproterozoic to Eocene time Tethyan sediments, e.g., sandstones, mudstones, and carbonates are exposed (Gaetani and Garzanti, 1991).

The general trend of the Spiti River is NW-SE, which is more or less parallel to the major faults such as MCT, ISZ, and Karakorum Fault (KF), (Figure 1B). However, the local $\mathrm{N}$ and NNE trending Kaurik-Chango (K-C fault) and fault associated with Leo-Pargil horst in downstream reaches of the Spiti River are responsible for the abrupt change in its course (Molnar and Chen, 1983). In the Spiti valley, Tethyan sediments of Neoproterozoic to
Cretaceous are exposed (Sinha, 1989; Bhargava and Bassi, 1998; Srivastava et al., 2013).

\section{SEDIMENTARY ARCHIVES AND PROXIES FOR PALAEOCLIMATE}

The Quaternary sedimentary archives preserve palaeoclimatic signatures, and this becomes even important in areas having an abundant supply of sediments with unstable tectono-climatic setup, e.g., NW India. Vegetation based proxy, e.g., Pollen, Spore, Phytolith, are robust climatic tool to draw inferences over the climatic set up of the particular region (Bhattacharyya, 1989; Demske et al., 2009), however, the scope becomes rather limited if the region is a desert with scanty vegetation cover. Except for some lake sequences, it is very difficult to get biotic proxy signals in the Quaternary sediments because the organic matter gets readily oxidized (Sekar et al., 1994; Shukla et al., 2002). Interestingly, the Ladakh and Spiti regions, however, have widely distributed variety of landforms of glacial, fluvial, lacustrine, and aeolian origin (Figure 2) and have been exploited for extracting the palaeoclimatic information by applying physical and geochemical proxy parameters (Fort et al., 1989; Phartiyal et al., 2005; Dortch et al., 2013; Srivastava et al., 2013; Kumar et al., 2017). Among glacial landforms, moraines and large erratic 
stones (moraine boulders) are used widely for estimating the glacial stages by geomorphic field mapping, remote sensing and ${ }^{10} \mathrm{Be}$ terrestrial cosmogenic nuclide surface exposure dating (Brown et al., 2002; Dortch et al., 2010, 2013). Similarly, fluvial terraces, the sedimentary structures preserved therein and also the texture, mineralogy, geochemistry and environmental magnetic parameters are successfully used for the palaeoclimatic reconstructions by several workers in different parts of the subcontinent (Chauhan et al., 2013; Prasad et al., 2014; Raj et al., 2015; Bhushan et al., 2018). Pro-glacial, glacial, freshwater and even saline lakes distributed in the Ladakh and Spiti regions are also exploited using both biotic and abiotic proxies to draw climatic inferences (see Table 1).

A $23 \mathrm{~m}$ sediment core of Tsokar lake dated by ${ }^{14} \mathrm{C}$ radiocarbon technique and studied for the its pollen record elaborates four phases of climate amelioration at 28,000-30,000 yr B.P., 21,00018,375 yr B.P., slightly before $15,800 \mathrm{yr}$ B.P. and $10,000 \mathrm{yr}$ B.P. On the basis of Juniperus communities expansion within alpine steppe (Bhattacharyya, 1989). Sekar et al. (1994) also suggested similar climatic conditions based on the analysis of elemental, organic and mineral content variations with slight asynchronous events from the Tsokar lake, Ladakh. After two decades, Demske et al. (2009) revisited the Tsokar Lake and using the same palynological and chronological techniques, fine-tuned the records indicating increased moisture conditions between ca. 12.9 and $12.5 \mathrm{kyr}$ BP, followed by extremely weak moisture conditions at ca. 12.2-11.8 kyr BP. They also reported peak monsoon between ca. 10.9 and $9.2 \mathrm{kyr}$ BP. A moderate reduction in moisture from ca. 9.2 to $4.8 \mathrm{kyr}$ $\mathrm{BP}$, but noted high lake levels around $8 \mathrm{kyr}$ BP. They also recorded an abrupt shift to arid conditions after ca. $4.8 \mathrm{kyr}$ BP that continued till ca. 2.8-1.3 kyr BP. The interplay of Monsoon and Westerly wind systems were probably governing the climatic fluctuations. Similar palaeoclimate results were derived by Wünnemann et al. (2010) by geomorphological, geochemical and palynological investigations. This study also discusses the hydrological evolution of Tsokar Lake Basin in past $15 \mathrm{kyr}$. High resolution isotopic $\left(\delta^{18} \mathrm{O}\right.$ and $\left.\delta^{13} \mathrm{C}\right)$ investigations on endogenic carbonates from Tso Moriri Lake, Ladakh concluded an increasing ISM precipitation between ca. 13.1 and $11.7 \mathrm{cal} \mathrm{ka}$ and highest ISM precipitation during the 11.2-8.5 cal ka (Mishra et al., 2015). Detailed geochemical, mineralogical and sedimentological analysis reveals that Tso Moriri witnessed several short-term fluctuations with seven major palaeohydrological stages since $\sim 26$ cal ka (Mishra et al., 2014). Recently, the OSL dating of aeolian deposits, particularly the sand ramps of the Ladakh area suggest that the aggradations in valley occurred in three pulses, at $\sim 52, \sim 28$, and $\sim 16 \mathrm{ka}$, and these pulses broadly coincide with periods of stronger ISM (Kumar et al., 2017).

In a relatively recent work Blöthe et al. (2014) reviewed the earlier works as well as did field mapping including lithology and chronology of glacial, fluvial and lacustrine deposits of the Indus and Zanskar confluence and adjoining areas. Accordingly, they concluded that the region experienced at least two episodes of massive infilling during the late Pleistocene. The older episode may have occurred after $530 \mathrm{ka}$, followed by pronounced incision at $\sim 200 \mathrm{ka}$. The remnants of the former valley floor, which is currently lying up to 200-300 $\mathrm{m}$ above the present river levels, are signs of the older episode. The younger episode of infilling, however, occurred between 50 and $20 \mathrm{ka} \mathrm{BP}$. They also suggested that lakes existed for longer time periods $\left(10^{3}-10^{4} \mathrm{yr}\right)$ than the previously estimated. However, the causative factor behind the lake formation was the same as proposed by Phartiyal et al. (2005).

Interestingly, Blöthe et al. (2014) also concluded that there is no direct relationship between the sequence of late Quaternary valley incision and backfill with proxies of the ISM. However, post and inter-glacial sediment pulses are relatively better correlated. Additionally, they emphasized that tectonics is not the major player in the landscape evolution of the trans-Himalayan region because the drainage configuration has not changed significantly during the last $\sim 120$ ka. However, soft sedimentary deformation structures indicating tectonic activity are also reported from several fluvio-lacustrine deposits (Phartiyal and Sharma, 2009), concentrating mostly $\sim 10 \mathrm{ka}$ and $6 \mathrm{ka} \mathrm{BP}$ (Nag and Phartiyal, 2015).

The areal extent of Ladakh region is many orders more than the Spiti valley. However, the landscape evolution of the two regions is pretty similar. The signatures of neotectonic activity in the Spiti region are more pronounced, whereas in Ladakh these are rather subdued (Singh et al., 1975; Singh and Jain, 2007; Phartiyal et al., 2009a; Srivastava et al., 2013; Blöthe et al., 2014). There are many tributary valleys of Indus River such as Zanskar, Shyok, Suru, that may be independently compared with the Spiti River valley and the sediment deposits found along the longitudinal profile of these rivers are also comparable. Based on the relative stratigraphy and the geometry of fluvial and lacustrine deposits distributed across these regions, it is inferred that the channel damming is the most effective process in their formation. The damming is largely governed by the tectono-climatic factors that may either be catastrophic landslides, rainfall-induced debris flow or fan building (Fort et al., 1989; Phartiyal et al., 2005). A summary of the Quaternary palaeoclimate works carried out in the region by several workers is presented here in the chronological order in tabular form as a ready reference and illustrated for better understanding (see Table 1 and Figure 4) of the subject.

\section{SOURCE OF MOISTURE}

There are two major sources of moisture in this region, viz. ISM and central Asian westerlies [Western disturbances (WD)/Winter Monsoon (WM)] (Figure 5). Monsoon is a highly complex phenomenon, and over the years, studies carried out have extended its spread from local to regional and presently to global scale. In a recent study, Zhisheng et al. (2015) summarized that "The global monsoon is the significant seasonal variation of three-dimensional planetaryscale atmospheric circulations forced by seasonal pressure system 
TABLE 1 | Summary table of climatic history in the trans-Himalayan region (Ladakh and Spiti Valley).

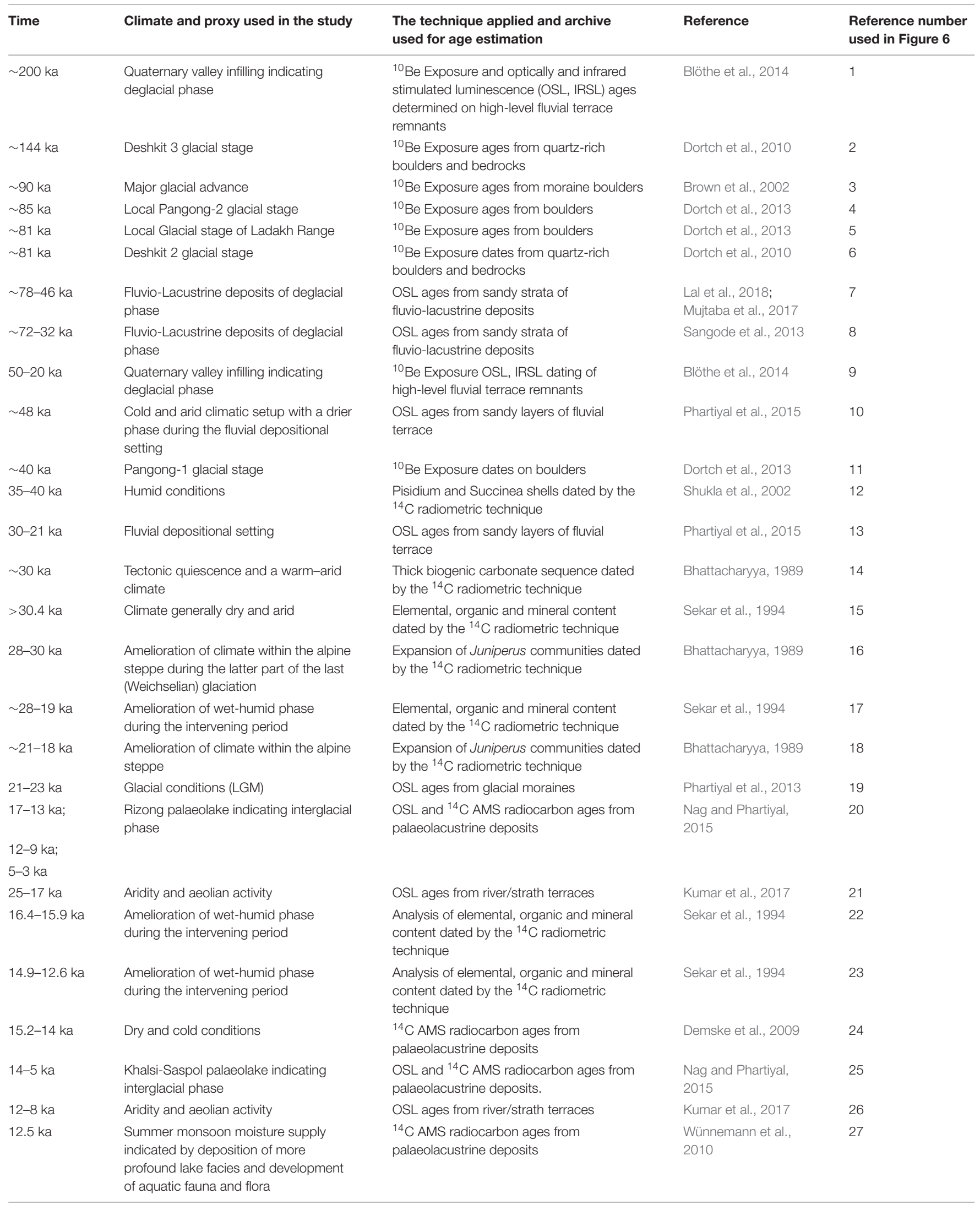


TABLE 1 | Continued

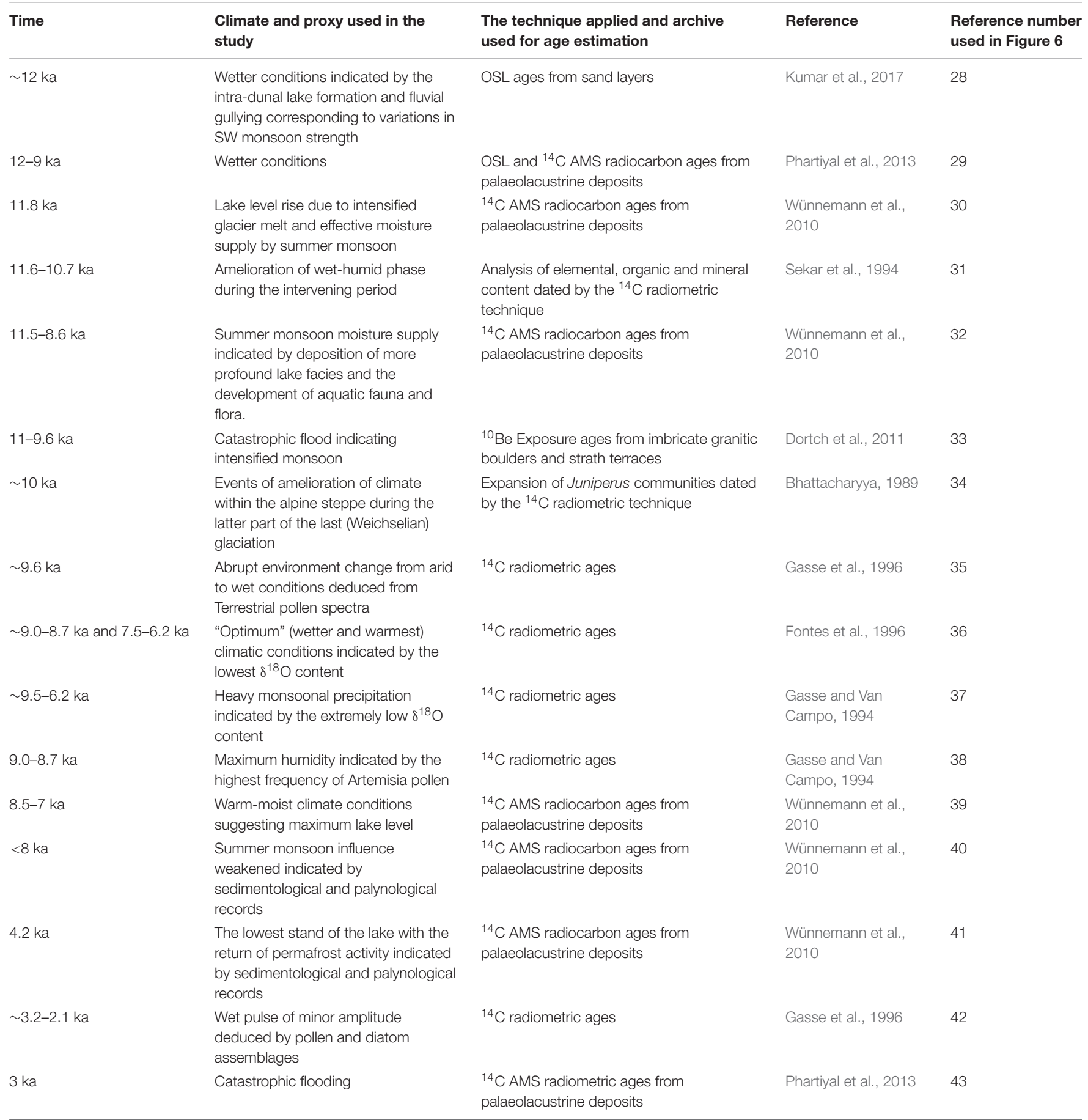

shifts driven jointly by the annual cycle of solar radiative forcing and land-air-sea interactions. The seasonal reversal of prevailing wind direction and a seasonal alternation of dry and wet conditions characterize the associated surface climate". Similarly, the central Asian westerlies are low-pressure waves embedded in the mid-latitude subtropical westerly jet that travel from West to the East bringing moisture from the Mediterranean Sea and the Atlantic Ocean (Dimri et al.,
2015; Dimri and Chevuturi, 2016) and modulate the winters. Depending on the intensity of these waves, different regions receive precipitation either in the form of snow/ice, fog or showers. Most of the studies referred above discuss the meteorological parameters and related dynamics. However, the water isotopic composition based studies from the Ladakh/Upper Indus Basin are scanty, more so conflicting and dealt in the discussion section. 

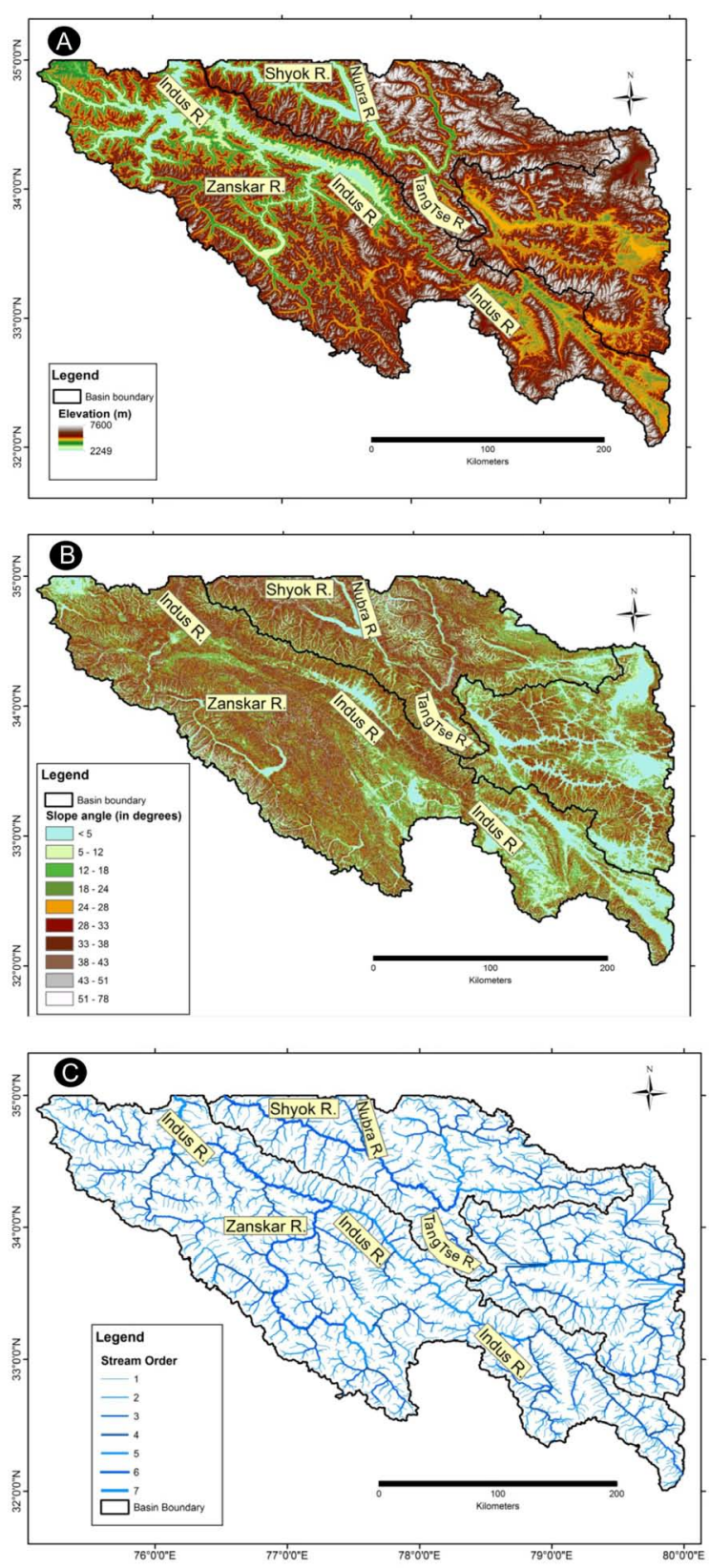

FIGURE 4 | Three maps panel of Upper Indus Basin Catchment (A) Map showing the altitude (DEM) variation within the catchment. (B) The slope map showing appreciable variation in the slope angle in a relatively limited distance of $\sim 400 \mathrm{~km}$ course of the Indus River. (C) The drainage map of the Indus catchment showing its major tributaries and minor streams. It is interesting to note that river Indus has attained 7th stream order, a feature usually seen in mountainous terrenes only.

It is well accepted now that the ISM is a manifestation of the seasonal migration of the Inter-Tropical Convergence Zone (ITCZ) (Figure 5). However, the intensity of rainfall and its latitudinal-location is still unanswered (Schneider et al., 2014; Gadgil, 2018). The region also receives relatively more rain/snow during Abnormal Monsoon Years (AMYs) due to a northward shift of the ITCZ (Bookhagen et al., 2005). Besides, the region seldom experiences unpredictable climatic conditions, e.g., in the year 2010 the Leh city and adjoining areas were devastated by the cloudburst wherein $210 \mathrm{~mm}$ precipitation occurred only in $3 \mathrm{~h}$ period causing a destructive flash flood (Juyal et al., 2010; Arya, 2011; Rasmussen and Houze, 2012). Such extreme events, in geological past, may have triggered the landslides responsible for damming the stream flow and thereby forming the lakes as suggested by several workers (Pant et al., 2005; Phartiyal et al., 2005, 2013).

\section{CHRONOLOGY: ADVANTAGES AND LIMITATIONS}

Chronology of geological events has immense significance in geological sciences. Conventional and AMS ${ }^{14} \mathrm{C}$ radiometric dating is the most widely used technique and successfully used by numerous workers (Bhattacharyya, 1989; Demske et al., 2009; Phartiyal et al., 2009a,b, 2005; Wünnemann et al., 2010). Presence of measurable organic carbon content in sediment limits the application of conventional radiocarbon method to be employed. In glaciated barren terrains, e.g., Ladakh and Spiti valley, we have used conventional ${ }^{14} \mathrm{C}$ radiometric dates in our initial publications (Phartiyal et al., 2005; Phartiyal and Sharma, 2009), however, we started facing problems due to reservoir effect (preaged organic carbon or ${ }^{14} \mathrm{C}$-depleted hard water) (Doran et al., 1999; Halla and Henderson, 2001; Wagner et al., 2004; Zhou et al., 2015). To overcome this meager availability of organic carbon, as much as possible, we started using ${ }^{14} \mathrm{C}$ AMS dates. In our endeavor to revisit the palaeolake deposits of Spituk area near Leh city in Ladakh, the ${ }^{14} \mathrm{C}$ AMS dates that we have received are much younger (Phartiyal et al., 2013) than the one we have analyzed by the conventional ${ }^{14} \mathrm{C}$ dating techniques of the same sequence (Phartiyal et al., 2005). Optical ages from this sequence have yielded age estimates that are similar or older than conventional radiocarbon ages (Sangode et al., 2013; Blöthe et al., 2014; Lal et al., 2018) as shown in Figure 6.

Regarding optical dating, Morthekai et al. (2017) suggest that one needs to be cautious while using quartz to obtain chronology, particularly in a geological terrain like Ladakh and Spiti valley. Feldspar's inherent problem of anomalous fading affects the chronology, and hence it is avoided when quartz portion is sufficient. The reason for being cautious, as Morthekai et al. (2017) stated that quartz is not only 'dull' (low sensitivity to ionizing radiation) but also heterogeneously bleached (poor resetting of latent geological signals) and may lead to erroneous results. In this work, the authors have shown that the bigger the aliquots (with many quartz grains) yield over-estimated ages with small over-dispersion in the data.

Similarly, in cosmogenic exposure ${ }^{10} \mathrm{Be}$ chronology, certain assumptions need to be made toward understanding the geological history of the sample. These assumptions are difficult to test and therefore may cause a profound effect on the inferred age. In a review work over palaeoglaciation in Tibetan region, Heyman et al. (2011) have shown that two principal geological 


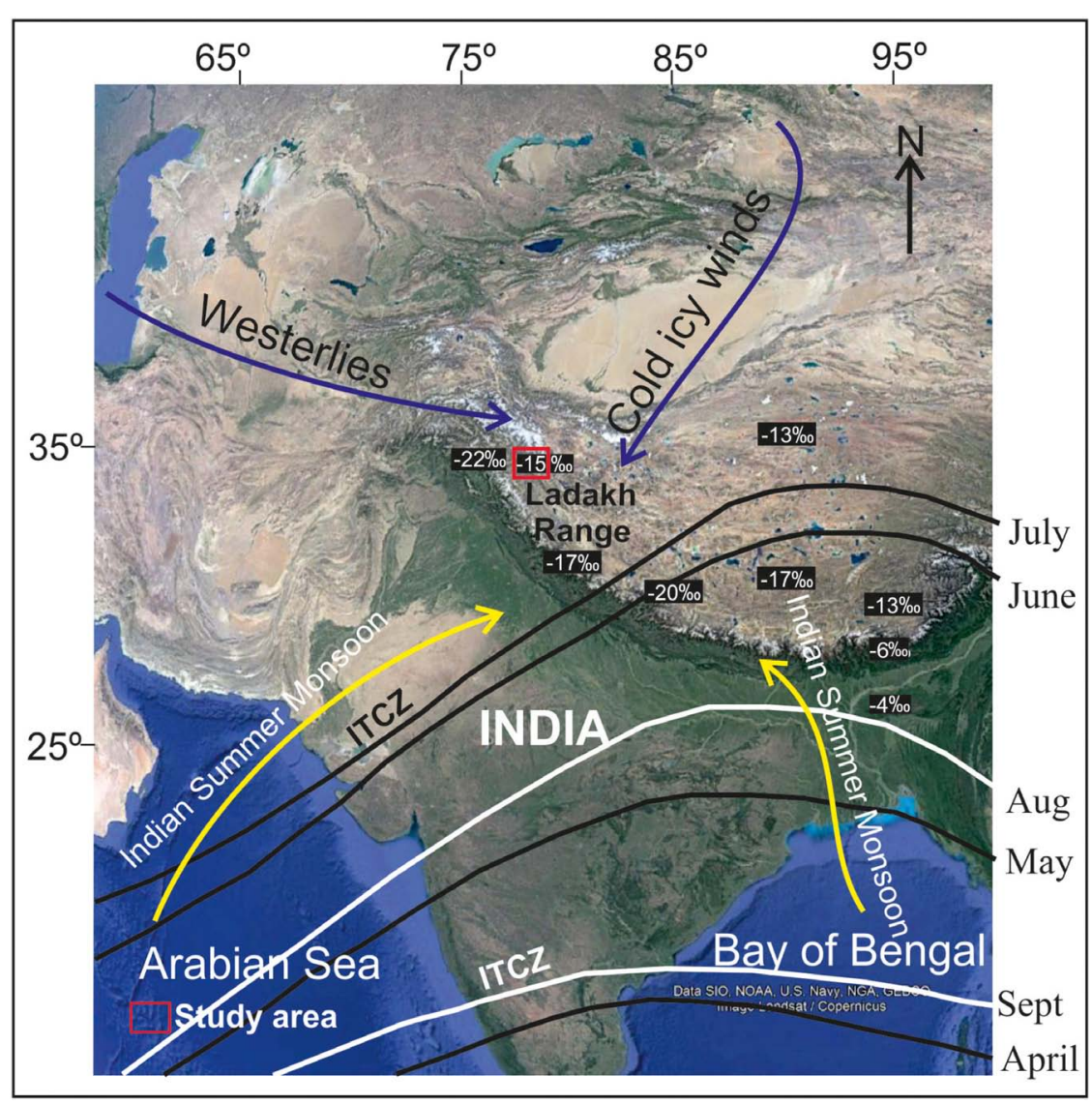

FIGURE 5 | Google image of India showing different moisture sources to NW trans-Himalayan regions. Also shown the position of ITCZ during ISM (source for ISM trend lines: https://www.pmfias.com/indian-monsoons-south-west-north-east-monsoons-itcz/). The solid black and white ITCZ trend-lines showing that with increasing temperature, the ITCZ keeps moving northward (April-July) and from August onwards, the direction of ITCZ trend becomes southward, respectively. It is important to note that in abnormal monsoon years (ITCZ moves further north), appreciable amounts of monsoon winds crossover the Himalayas and bring more rain and snow to trans-Himalayan regions. The $\delta^{18} \mathrm{O}$ isotopic composition is also marked in the figure (for details see Sharma et al., 2017).

factors (1) Exposure before glaciation and (2) Incomplete exposure due to post-depositional shielding may yield exposure ages that are either too old or too young, respectively. Therefore, it is essential that more emphasis must be given to understand the geological features and processes to ascertain the relative stratigraphy of a region. And based on this a combination of different dating techniques is to be applied for establishing the chronology, particularly in regions like trans-Himalayan terrains of NW India and employing a single technique may mislead.

\section{DISCUSSION}

In our research endeavors in the Ladakh and Spiti regions of NW India, primarily dedicated to the Quaternary geomorphology and fluvio-lacustrine deposits, we have carried out extensive field reconnaissance surveys supported with laboratory-based dataset, and discussed the landscape evolution and paleoclimate of the region in our publications (Phartiyal et al., 2005, 2009a,b, 2005, 2013, 2015; Phartiyal and Sharma, 2009; Srivastava et al., 2013; Nag et al., 2016) and still continuing with it. A cursory look of the geomorphological signatures present in the entire NW Himalayan region (Figures 1-3) indicates that the region has experienced glacial advance (glacial phase) and retreat (interglacial phase) at different time intervals.

The fluvial and lacustrine regime was dominating in the interglacial phase. However, their timing and duration are still debatable. The aeolian activity interspersed between the glacial and interglacial phases noticed in the form of dune and sand ramps indicating dry climatic phases. A summary of climate based geomorphic expressions along with chronology is presented in Table $\mathbf{1}$ and illustrated in Figure $\mathbf{4}$ and readers may refer to the relevant reference for the comprehensive understanding of the subject. Although several authors have attempted to see the correlation between late Pleistocene to early Holocene fluvio-lacustrine deposits with monsoon proxies (see Table 1 and reference therein), however, no consensus has so far evolved due to chronological issues and dealt in the following section.

To highlight the discrepancy in chronological techniques, we are presenting the case study of one of the section, among many others, the Spituk palaeolake sequence $\left(34.13246{ }^{\circ} \mathrm{N}\right.$; 


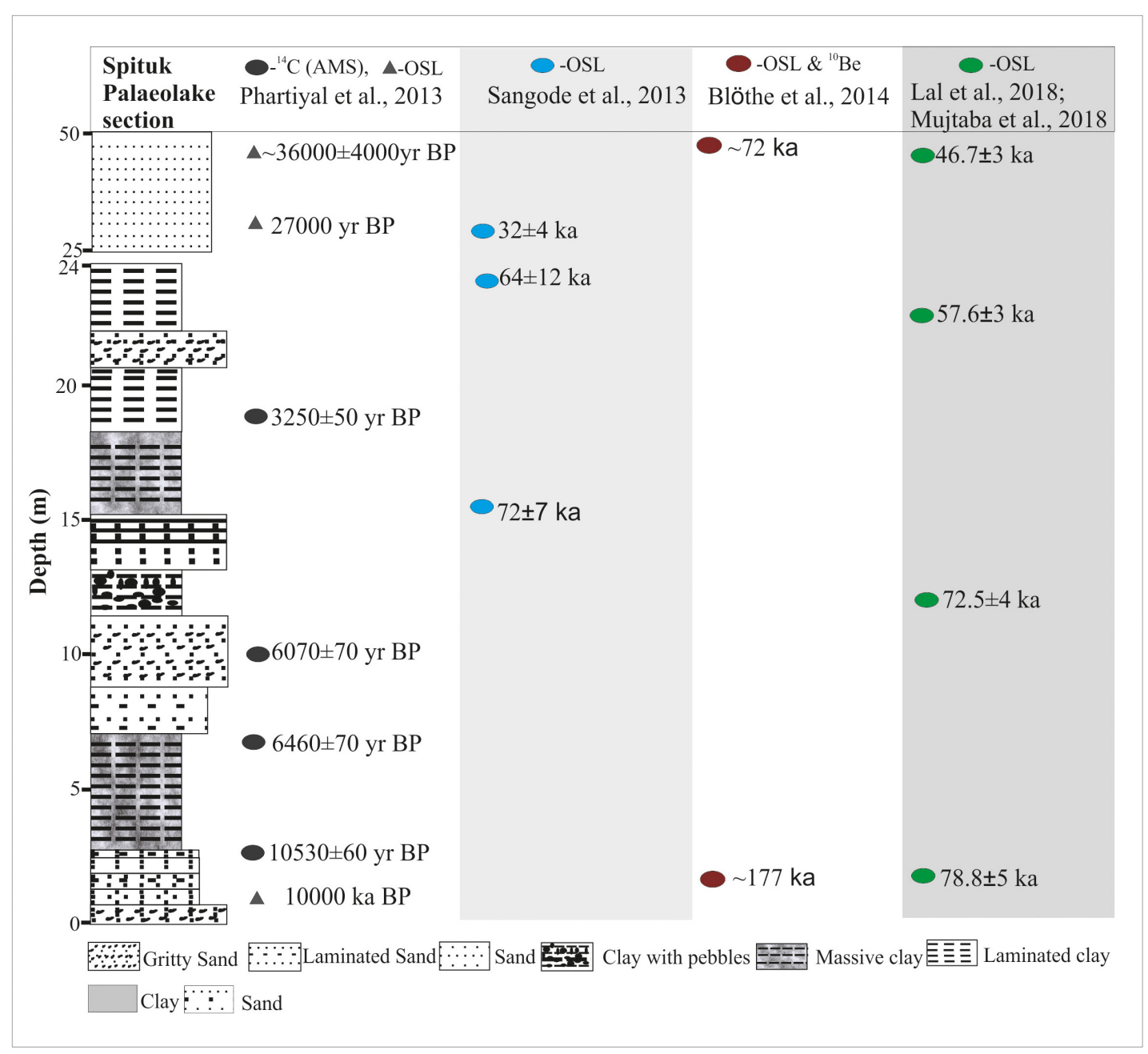

FIGURE 6 | Litholog of Spituk palaeolake sedimentary sequence situated near Leh city on the right bank of the Indus River on Leh-Srinagar road used as an example to explain age discrepancy. The lithological description of the section is fairly consistent in studies carried out by different workers. However, there is a discrepancy in age estimated through different dating techniques (see text for details).

$77.52563{ }^{\circ} \mathrm{E}$ ) exposed on the right bank of the Indus river. Several workers study this sedimentary sequence and have given the chronology for the same sequence (Phartiyal et al., 2005, 2013; Sangode et al., 2013; Blöthe et al., 2014; Mujtaba et al., 2017; Lal et al., 2018) (Figure 6). So far as the sediment facies present in the entire $>50 \mathrm{~m}$ sequence is concerned, there is a fairly good understanding among the authors that how incision followed by the fluvial aggradation and subsequent lacustrine facie deposition took place in the Spituk locality, however, the chronology is disturbed. Altogether three dating techniques were applied for establishing the chronology of the Spituk section, i.e., conventional ${ }^{14} \mathrm{C}$ radiometric and AMS dating by Phartiyal et al. (2005, 2013), respectively. All other authors used the OSL/IRSL technique to date this sequence (Sangode et al., 2013; Blöthe et al., 2014; Mujtaba et al., 2017; Lal et al., 2018). The conventional ${ }^{14} \mathrm{C}$ radiometric date bracketed between $\sim 50$ and $\sim 30 \mathrm{ka}$. However, it reduced to $\sim 10.5-3.2 \mathrm{ka}$ when ${ }^{14} \mathrm{C}$ AMS technique is applied (see Figure 6).
Similarly, the three other age brackets using OSL/IRSL technique are $\sim 72$ to $\sim 32 \mathrm{ka}$ (Sangode et al., 2013), $\sim 177$ to $\sim 72 \mathrm{ka}$ (Blöthe et al., 2014) and 78.8-46.7 ka (Figure 6) (Mujtaba et al., 2017; Lal et al., 2018) showing considerable variation beyond the error range. The discrepancy observed in ages indicates that more work is required to address this issue, at least for regions like Himalaya or similar orogen. Interestingly, a solitary date obtained by OSL technique of the bottom sand of this section by Phartiyal et al. (2013) is also $\sim 10 \mathrm{ka}$ (Figure 6). These two dates of $\sim 10 \mathrm{ka}$ obtained through both OSL and ${ }^{14} \mathrm{C}$ AMS techniques made us believe that these are most likely the correct ages. As we have only one such set of comparable dates obtained from two different techniques, more such sets of samples are required to address this important issue and looking at the arguments by Morthekai et al. (2017) further work in this direction is under progress.

In the Quaternary palaeoclimatology study, it is a common practice that authors usually employ several climate 
proxy parameters over an exposed sedimentary section or a sediment core. Because multiproxy climate data generation is a tedious and time taking practice, often less emphasis is given to generate a relative stratigraphy of the region. Under such conditions, there is no choice left but to completely rely on the results obtained through the absolute dating techniques. On the contrary, often distinctly different climatic inferences are drawn in a much-localized area as is the case of Spituk section referred above. This kind of intra/inter dating technique limitations bring serious discrepancy in the climatic record, which is otherwise not possible. Therefore, adequate precaution is to be required, so as a comprehensive understanding on the processes involved, interlinkages in different proxy parameters and the combination of dating technique with comparable ages will enable us to propose the palaeoclimatic history of a particular region.

Similarly, the contribution of dominant moisture sources to the NW trans-Himalayan regions is another challenging issue. It is for long believed that the moisture source is dominantly (2/3 of the total) contributed by the westerlies and ISM contribution is only $1 / 3$ of the total precipitation received to the trans-Himalayan regions (Mayewski et al., 1980; Goudie et al., 1984; Searle, 1991). In a study using oxygen and hydrogen isotopic values of the Indus River in the Pakistan territory, Karim and Veizer (2002) proposed that $\sim 74 \%$ of the moisture comes from the Mediterranean region and the other sources contribute only $26 \%$ of the total moisture received annually. However, in our study carried out in the Ladakh region of the Indus, its tributaries and other smaller streams water isotopic composition along with two end-member mixing model and the mass balance calculations, we (Sharma et al., 2017) demonstrated that in the main Indus channel flow, only $\sim 26 \%$ contribution is received from the Mediterranean source, and the ISM contributes the rest. These values are fairly consistent with Pande et al. (2000) from the same region and significantly different from the Karim and Veizer (2002).

Further, it is to be noted here that if the dominant source of moisture is from the Mediterranean region, the isotopic including the d-excess values must be more depleted in Ladakh as compared to Hindukush region of Pakistan because the Ladakh is situated further east of the Hindukush and relatively more distant from the Mediterranean region (continentality effect). However, the measured isotopic composition of the Indus, its major and minor tributaries, all showing less depleted values, which implies that ISM contribution, is also a dominant source to the trans-Himalayan region (Sharma et al., 2017). In a recent study by Shafiq et al. (2016), wherein the authors carried out the time series analysis of precipitation recorded at Leh from the year 1901 to 2000, also reported that the summer months average precipitation is relatively more $(30.67 \mathrm{~mm})$ as compared to the average winters $(27.38 \mathrm{~mm})$. However, the trend is showing a marginal decrease in summer precipitation and complimentary

\section{REFERENCES}

Achenbach, H. (2010). New findings concerning the Pleistocene Glaciation of the Leh Basin, Ladakh ( $34^{\circ} 03^{\prime} \mathrm{N} / 77^{\circ} 38^{\prime}$ E). J. Mountain Sci. 7, 367-374. doi: 10.1007/s11629-010-2027-x increase in the winter precipitation. Since the long-term water/ice isotopic data record from this region is inadequate, efforts need to be made in this direction to generate more from this region. As mentioned earlier also, that fresh water supply to a large fraction of the global population is dependent on the Himalayan glaciers, the significance of water isotopic studies become, even more, important and have wider implications.

\section{CONCLUSION}

(1) The India-Asia collision primarily governs the geomorphological evolution of the trans-Himalayan region of NW India. Subsequently, the Quaternary glacial and interglacial processes modified the landscape and responsible for the present geomorphic setup of the region.

(2) Climate proxy parameters provide important information over glacial and interglacial regimes, but the discrepancy in chronology needs serious relooking for the better palaeoclimatic record.

(3) The Mediterranean and Indian Summer Monsoon winds are bringing moisture to the trans-Himalayan region more or less equally. More long-term work employing time series analysis is required to address the issue of moisture contribution from different sources having wider implications.

\section{AUTHOR CONTRIBUTIONS}

AS had plotted the concept of the manuscript. AS and BP had contributed in writing the manuscript.

\section{ACKNOWLEDGMENTS}

We are thankful to the Director of Birbal Sahni Institute of Palaeosciences, Lucknow for supporting us for last several years to carry out the research work in the Ladakh and Spiti regions of NW India (Permission No. BSIP/RDCC/Publication No. 94/2017-18). We are also thankful to our collaborators and field parties for fruitful discussions and logistic support. We also like to extend our thanks to new members of our team having expertise in glacial and optical dating techniques and field parties for fruitful discussion and logistic support. We thank Mr. Randheer Singh, Ms. Shazi Farooqui, Mr. Mukesh Yadav, and Mr. Jitendra Yadav for extending assistance including technical support. We are also thankful to two reviewers for their constructive comments, which helped us to make the article more focused and presentable.

Ahmad, M., Latif, Z., Tariq, J. A., Rafique, M., Akram, W., Aggarwal, P., et al. (2012). "Isotope investigations of major rivers of Indus Basin, Pakistan," in Proceedings of the Monitoring Isotopes in Rivers: Creation of the Global Network of Isotopes in Rivers (GNIR) Results of a Coordinated Research Project 2002-2006, Vienna: IAEA-TECDOC-1673. 
Ali, S. N., Thakur, B., Morthekai, P., Farooqui, S., Phartiyal, B., Seth, P. A., et al. (2018). Diatom Diversity Under Extreme Climate: a study from Zanskar valley, NW Himalaya, India. J. Palaeonto. Soc. India 63, 119-126.

Arya, R. (2011). Leh floods 2010. An extreme geological event. Disast. Dev. 5, 103-129.

Bennett, M. M., and Glasser, N. F. (2011). Glacial Geology: Ice Sheets and Landforms. Hoboken, NJ: John Wiley \& Sons.

Bhargava, O. N., and Bassi, U. K. (1998). Geology of Spiti-Kinnaur, Himachal Himalaya. Geol. Survey India Memoirs 124, 1-210.

Bhattacharyya, A. (1989). Vegetation and climate during the last 30,000 years in Ladakh. Palaeogeogr. Palaeoclimatol. Palaeoecol. 73, 25-38. doi: 10.1016/00310182(89)90042-4

Bhushan, R., Sati, S. P., Rana, N., Shukla, A. D., Mazumdar, A. S., and Juyal, N. (2018). High-resolution millennial and centennial scale Holocene monsoon variability in the Higher Central Himalayas. Palaeogeogr. Palaeoclimatol. Palaeoecol. 489, 95-104. doi: 10.1016/j.palaeo.2017.09.032

Blöthe, J. H., Munack, H., Korup, O., Fülling, A., Garzanti, E., Resentini, A., et al. (2014). Late Quaternary valley infill and dissection in the Indus River, western Tibetan Plateau margin. Quatern. Sci. Rev. 94, 102-119. doi: 10.1016/j. quascirev.2014.04.011

Bookhagen, B. (2012). Hydrology: himalayan groundwater. Nat. Geosci. 5, 97-98. doi: 10.1038/ngeo1366

Bookhagen, B., Thiede, R., and Strecker, M. R. (2005). Abnormal Monsoon years and their control on erosion and sediment flux in the high, arid northwestern Himalaya. Earth Planet. Sci. Lett. 231, 131-146. doi: 10.1016/j.epsl.2004.11.014

Brown, E. T., Bendick, R., Bourlès, D. L., and Gaur, V. K. (2002). Slip rates of the Karakorum fault, Ladakh, India, determined using cosmic ray exposure dating of debris flows and moraines. J. Geophys. Res. 107:2192. doi: 10.1029/ 2000JB000100

Chauhan, M. S., Sharma, A., Phartiyal, B., and Kumar, K. (2013). Holocene vegetation and climatic variations in Central India: a study based on multiproxy evidences. J. Asian Earth Sci. 77, 45-58. doi: 10.1016/j.jseaes.2013. 08.005

Clift, P. D., Hodges, K. V., Heslop, D., Hannigan, R., Van Long, H., and Calves, G. (2008). Correlation of Himalayan exhumation rates and Asian monsoon intensity. Nat. Geosci. 1, 875-880. doi: 10.1038/ ngeo351

Dainelli, G. (1922). "Studi sul glaciale," in Relazione cientifiche della Spedizione Italiana de Filippi, Nell'Himalaia, Caracorum e Turchestan Cinese (1913-1914), Serie 2, Resultati Geologici e Geografici, Vol. 3 (Bologna: Nicola Zanichelli), 658.

Demske, D., Tarasov, P. E., Wünnemann, B., and Riedel, F. (2009). Late Glacial and Holocene vegetation, Indian monsoon and westerly circulation in the transHimalaya recorded in the lacustrine pollen sequence from Tso Kar, Ladakh, NW India. Palaeogeogr. Palaeoclimatol. Palaeoecol. 279, 172-185. doi: 10.1016/ j.palaeo.2009.05.008

Dimri, A. P., and Chevuturi, A. (2016). Western Disturbances - An Indian Meteorological Perspective. Cham: Springer International Publishing, doi: 10.1007/978-3-319-26737-1

Dimri, A. P., Niyogi, D., Barros, A. P., Ridley, J., Mohanty, U. C., Yasunari, T., et al. (2015). Western Disturbances: a review. Rev. Geophys. 53, 225-246. doi: 10.1002/2014RG000460

Doran, P. T., Berger, G. W., Lyons, W. B., Wharton, R. A. Jr., Davisson, M. L., Southon, J., et al. (1999). Dating quaternary lacustrine sediments in the mcmurdo dry valleys Antarctica. Palaeogeogr. Palaeoclimatol. Palaeoecol. 147, 223-239. doi: 10.1016/S0031-0182(98)00159-X

Dortch, J. M., Dietsch, C., Owen, L. A., Caffee, M. W., and Ruppert, K. (2011). Episodic fluvial incision of rivers and rock uplift in the Himalaya and Transhimalaya. J. Geol. Soc. 168, 783-804. doi: 10.1144/0016-76492 009-158

Dortch, J. M., Owen, L. A., and Caffee, M. W. (2010). Quaternary glaciation in the Nubra and Shyok valley confluence, northernmost Ladakh, India. Quatern. Res. 74, 132-144. doi: 10.1016/j.yqres.2010.04.013

Dortch, J. M., Owen, L. A., and Caffee, M. W. (2013). Timing and climatic drivers for glaciation across semi-arid western Himalayan Tibetan orogen. Quatern. Sci. Rev. 78, 188-208. doi: 10.1016/j.quascirev.2013.07.025

Edmond, J. M., and Huh, Y. (1997). "Chemical weathering yields from basement and orogenic terrains in hot and cold climates", in Tectonic Uplift and Climate Change, ed. W. F. Ruddiman (New York, NY: Plenum Press), 330-353.
Fontes, J. C., Gasse, F., and Gibert, E. (1996). Holocene environmental changes in Lake Bangong basin (Western Tibet). Part 1: Chronology and stable isotopes of carbonates of a Holocene lacustrine core. Palaeogeogr. Palaeoclimatol. Palaeoecol. 120, 25-47. doi: 10.1016/0031-0182(95)00032-1

Fort, M. (1983). Geomorphological observations in the Ladakh area (Himalayas): Quaternary evolution and Present Dynamic. Contribut. Him. Geol. 2, 39-58.

Fort, M., Burbank, D. W., and Freytet, P. (1989). Lacustrine sedimentation in a semiarid alpine setting: an example from Ladakh, northwestern Himalaya. Quat. Res. 31, 332-350. doi: 10.1016/0033-5894(89)90041-0

Fuchs, G. (1981). Outline of the geology of the Himalaya. Mitteilungen der Österreichischen Geologischen Gesellschaft 74, 101-127. doi: 10.1038/s41598017-12908-0

Gadgil, S. (2018). The monsoon system: Land-sea breeze or the ITCZ? J. Earth Syst. Sci. 127, 1-29. doi: 10.1007/s12040-017-0916-x

Gaetani, M., and Garzanti, E. (1991). Multicyclic history of the northern India continental margin (northwestern Himalaya) (1). AAPG Bull. 75, 1427-1446.

Garzanti, E., and Van Haver, T. (1988). The Indus clastics: forearc basin sedimentation in the Ladakh Himalaya (India). Sediment. Geol. 59, 237-249. doi: 10.1016/0037-0738(88)90078-4

Gasse, F., Fontes, J. C., Van Campo, E., and Wei, K. (1996). Holocene environmental changes in Bangong Co basin (Western Tibet). Part 4: discussion and conclusions. Palaeogeogr. Palaeoclimatol. Palaeoecol. 120, 79-92. doi: 10.1016/0031-0182(95)00035-6

Gasse, F., and Van Campo, E. (1994). Abrupt post-glacial climate events in West Asia and North Africa monsoon domains. Earth Planet. Sci. Lett. 126, 435-456. doi: 10.1016/0012-821X(94)90123-6

Goudie, A. S., Jones, D. J. C., and Brunsden, D. (1984). “Recent fluctuations in some glaciers of western Karakoram Mountains, Hunza Pakistan," in International Karakoram Project, ed. K. Miller (Cambridge: Cambridge University Press), 441-455.

Guo, Z. T., Ruddiman, W. F., Hao, Q. Z., Wu, H. B., Qiao, Y. S., Zhu, R. X., et al. (2002). Onset of Asian desertification by $22 \mathrm{Myr}$ ago inferred from loess deposits in China. Nature 416:159. doi: 10.1038/416159a

Gupta, A. K., Anderson, D. M., and Overpeck, J. T. (2003). Abrupt changes in the Asian southwest monsoon during the Holocene and their links to the North Atlantic Ocean. Nature 421, 354-357. doi: 10.1038/nature01340

Halder, J., Terzer, S., Wassenaar, L. I., Araguás-Araguás, L. J., and Aggarwal, P. K. (2015). The Global Network of Isotopes in Rivers (GNIR): integration of water isotopes in watershed observation and riverine research. Hydrol. Earth Syst. Sci. 19, 3419-3431. doi: 10.5194/hess-19-3419-2015

Halla, B. L., and Henderson, G. M. (2001). Use of uranium-thorium dating to determine past $14 \mathrm{C}$ reservoir effects in lakes: examples from Antarctica. Earth Planet. Sci. Lett. 193, 565-577. doi: 10.1016/S0012-821X(01) 00524-6

Henderson, A. L., Najman, Y., Parrish, R., BouDagher-Fadel, M., Barford, D., Garzanti, E., et al. (2010). Geology of the Cenozoic Indus Basin sedimentary rocks: paleoenvironmental interpretation of sedimentation from the western Himalaya during the early phases of India-Eurasia collision. Tectonics 29, 1-35. doi: 10.1029/2009TC002651

Heyman, J., Stroeven, A. P., Harbor, J. M., and Caffee, M. W. (2011). Too young or too old: Evaluating cosmogenic exposure dating based on an analysis of compiled boulder exposure ages. Earth Planet. Sci. Lett. 302, 71-80. doi: 10.1016/j.epsl.2010.11.040

Holmes, J. A. (1993). "Present and past patterns of glaciation in the northwest Himalaya: climatic, tectonic and topographic controls", in Himalaya to the Sea: Geology, Geomorphology and the Quaternary, ed. J. F. Shroder Jr. (London: Routledge), 72-90.

Hren, M. T., Bookhagen, B., Blisniuk, P. M., Booth, A. L., and Chamberlain, C. P. (2009). $\delta 180$ and $\delta$ D of stream waters across the Himalaya and Tibetan Plateau: implications for moisture sources and paleoelevation reconstructions. Earth Planet. Sci. Lett. 288, 20-32. doi: 10.1016/j.epsl.2009.08.041

Immerzeel, W. W., Van Beek, L. P., and Bierkens, M. F. (2010). Climate Change will Affect the Asian Water Towers. Science 328 (5984), 1382-1385. New Delhi: India Meteorological Department. doi: 10.1126/science.1183188

Jamieson, S. S. R., Sinclair, H. D., Kirstein, L. A., and Purves, R. S. (2004). Tectonic forcing of longitudinal valleys in the Himalaya: morphological analysis of the Ladakh Batholith, North India. Geomorphology 58, 49-65. doi: 10.1016/S0169555X(03)00185-5 
Juyal, N., Sundriyal, Y., Rana, N., Chaudhary, S., and Singhvi, A. K. (2010). Late Quaternary fluvial aggradation and incision in the monsoon-dominated Alaknanda valley, Central Himalaya Uttrakhand India. J. Quat. Sci. 25, 1293-1304. doi: 10.1002/jqs.1413

Karim, A., and Veizer, J. (2000). Weathering processes in the Indus River Basin: implications from riverine carbon, sulfur, oxygen, and strontium isotopes. Chem. Geol. 170, 153-177. doi: 10.1016/S0009-2541(99)00246-6

Karim, A., and Veizer, J. (2002). Water balance of Indus river basin and moisture source in the Karakoram and western Himalayas: implications from hydrogen and oxygen isotopes in river water. J. Geophys. Res. 107:(ACH9-1-ACH9-12). doi: 10.1029/2000JD000253

Klootwijk, C. T., Conaghan, P. J., and Powell, C. McA. (1985). The Himalayan Arc: large-scale continental subduction, oroclinal bending, and back-arc spreading. Earth Planet Sci. Lett. 75, 167-183. doi: 10.1016/0012-821X(85)90099-8

Koppes, M. N., and Montgomery, D. R. (2009). The relative efficacy of fluvial and glacial erosion over modern to orogenic timescales. Nat. Geosci. 2, 644-647. doi: $10.1038 /$ ngeo616

Kuhle, M. (1998). Reconstruction of the 2.4 million $\mathrm{km} 2$ late Pleistocene ice sheet on the Tibetan plateau and its impact on the global climate. Quat. Int. 45-46, 71-108. doi: 10.1016/S1040-6182(97)00008-6

Kumar, A., Srivastava, P., and Meena, N. K. (2017). Late Pleistocene aeolian activity in the cold desert of Ladakh: a record from sand ramps. Quat. Int. 443, 13-28. doi: 10.1016/j.quaint.2016.04.006

Kutzbach, J. E., and Otto-Bliesner, B. L. (1982). The sensitivity of the AfricanAsian monsoonal climate to orbital parameter changes for 9000 years BP in a low-resolution general circulation model. J. Atmos. Sci. 39, 1177-1188. doi: 10.1175/1520-0469(1982)039<1177:TSOTAA > 2.0.CO;2

Kutzbach, J. E., Prell, W. L., and Ruddiman, W. F. (1993). Sensitivity of Eurasian climate to surface uplift of the Tibetan Plateau. J. Geol. 101, 177-190. doi: $10.1086 / 648215$

Lal, R., Saini, H. S., Pant, N. C., and Mujtaba, S. A. I. (2018). Tectonics induced switching of provenance during the Late Quaternary aggradation of the Indus River Valley, Ladakh, India. Geosci. Front. 92, 102-119. doi: 10.1016/j.gsf.2017. 12.016

Lang, T. J., and Barros, A. P. (2004). Winter storms in the central Himalayas. J. Meteorol. Soc. Japan 82, 829-844. doi: 10.2151/jmsj.20 04.829

Mayewski, P. A., Pregent, G. P., Jeschke, P. A., and Ahmad, N. (1980). Himalayan and trans-Himalayan glacier fluctuations and the south Asian monsoon record. Arctic Alpine Res. 12, 171-182. doi: 10.2307/1550514

Mishra, P. K., Anoop, A., Jehangir, A., Prasad, S., Menzel, P., Schettler, G., et al. (2014). Limnology and modern sedimentation patterns in high altitude Tso Moriri Lake, NW Himalaya-implications for proxy development. Fundament. Appl. Limnol. Archiv für Hydrobiologie 185, 329-348. doi: 10.1127/fal/2014/ 0664

Mishra, P. K., Anoop, A., Schettler, G., Prasad, S., Jehangir, A., Menzel, P., et al. (2015). Reconstructed late Quaternary hydrological changes from Lake Tso Moriri, NW Himalaya. Quat. Int. 371, 76-86. doi: 10.1016/j.quaint.2014.11.040

Molnar, P., and Chen, W. P. (1983). Focal depths and fault plane solutions of earthquakes under the Tibetan Plateau. J. Geophys. Res. 88, 1180-1196. doi: 10.1029/JB088iB02p01180

Molnar, P., and Tapponnier, P. (1975). Cenozoic tectonics of Asia; effects of a continental collision. Science 189, 419-426. doi: 10.1126/science.189.4201.419

Morthekai, P., Sanjeevani, R., Nag, D., Chauhan, N., Shukla, A., Phartiyal, B., et al. (2017). Christ College (Autonomous), Thrissur, India. doi: 10.4103/0971-6203. 42748

Mujtaba, S. A. I., Lal, R., Saini, H. S., Kumar, P., and Pant, N. C. (2017). Formation and breaching of two palaeolakes around Leh, Indus valley, during the late Quaternary. Geol. Soc. 462, S462-S463.

Mukherji, A., Molden, D., Nepal, S., Rasul, G., and Wagnon, P. (2015). Himalayan waters at the crossroads: issues and challenges. Int. J. Water Resour. Dev. 31, 151-160. doi: 10.1080/07900627.2015.1040871

Nag, D., and Phartiyal, B. (2015). Climatic variations and geomorphology of the Indus River valley, between Nimo and Batalik, Ladakh (NW trans Himalayas) during late quaternary. Quat. Int. 371, 87-101. doi: 10.1016/j.quaint.2014. 08.045

Nag, D., Phartiyal, B., and Singh, D. S. (2016). Sedimentary characteristics of palaeolake deposits along the Indus River valley, Ladakh, Trans-Himalaya:
Implications for the depositional environment. Sedimentology 63, 1765-1785. doi: 10.1111/sed.12289

Owen, L. A., Caffee, M. W., Bovard, K. R., Finkel, R. C., and Sharma, M. C. (2006). Terrestrial cosmogenic nuclide surface exposure dating of the oldest glacial successions in the Himalayan orogen: Ladakh Range, northern India. Geol. Soc. Am. Bull. 118, 383-392. doi: 10.1130/B25750.1

Owen, L. A., and Derbyshire, E. (1989). The Karakoram glacial depositional system. Z Geomorphol. Suppl. 76, 33-73.

Owen, L. A., and Sharma, M. C. (1998). Rates and magnitudes of paraglacial fan formation in the Garhwal Himalaya: implications for landscape evolution. Geomorphology 26, 171-184. doi: 10.1016/S0169-555X(98)00057-9

Pande, K., Padia, J. T., Ramesh, R., and Sharma, K. K. (2000). Stable isotope systematics of surface water bodies in the Himalayan and trans-Himalayan (Kashmir) region. J. Earth Syst. Sci. 109, 109-115. doi: 10.1007/BF02719154

Pant, R. K., Phadtare, N. R., Chamyal, L. S., and Juyal, N. (2005). Quaternary deposits in Ladakh and Karakoram Himalaya: a treasure trove of the palaeoclimate records. Curr. Sci. 88, 1789-1798.

Phartiyal, B., and Sharma, A. (2009). Soft-sediment deformation structures in the Late Quaternary sediments of Ladakh: Evidence for multiple phases of seismic tremors in the North western Himalayan Region. J. Asian Earth Sci. 34, 761-770. doi: 10.1016/j.jseaes.2008.11.008

Phartiyal, B., Sharma, A., and Kothyari, G. C. (2013). Damming of River Indus during Late Quaternary in Ladakh Region of trans-Himalaya, NW India: Implications to Lake formation-climate and tectonics. Chin. Sci. Bull. 58, $142-155$.

Phartiyal, B., Sharma, A., Srivastava, P., and Ray, Y. (2009a). Chronology of relict lake deposits in the Spiti River, NW Trans Himalaya: implications to Late Pleistocenee Holocene climate-tectonic perturbations. Geomorphology 108, 264-272. doi: 10.1016/j.geomorph.2009.02.018

Phartiyal, B., Sharma, A., Upadhyay, R., and Ram-Awatar Sinha, A. (2005). Quaternary geology, tectonics and distribution of palaeo- and presentfluvio/glacio lacustrine deposits in Ladakh, NW Indian Himalaya e a study based on field observations. Geomorphology 65, 241-256. doi: 10.1016/j. geomorph.2004.09.004

Phartiyal, B., Singh, R., and Kothyari, G. C. (2015). Late-Quaternary geomorphic scenario due to changing depositional regimes in the Tangtse Valley, transHimalaya, NW India. Palaeogeogr. Palaeoclimatol. Palaeoecol. 422, 11-24. doi: 10.1016/j.palaeo.2015.01.013

Phartiyal, B., Singh, R., and Nag, D. (2018). "Trans and Tethyan-Himalayan Riversin reference to Ladakh and Lahaul Spiti, NW Himalaya, India," in The Indian Rivers: An Introduction for Science and Society, Springer Hydrogeology, Book Series (SPRINGERHYDRO), ed. D. S. Singh (Singapore: Springer), 367-382.

Phartiyal, B., Srivastava, P., and Sharma, A. (2009b). Tectono-Climatic signatures during late Quaternary Period from Upper Spiti Valley, NW Himalaya, Indian. Him. Geol. 30, 167-174.

Prasad, V., Farooqui, A., Sharma, A., Phartiyal, B., Chakraborty, S., Bhandari, S., et al. (2014). Mid-late Holocene monsoonal variations from mainland Gujarat, India: A multi-proxy study for evaluating climate culture relationship. Palaeogeogr. Palaeoclimatol. Palaeoecol. 397, 38-51. doi: 10.1016/j.palaeo.2013. 05.025

Rai, S. P., Thayyen, R. J., Purushothaman, P., and Kumar, B. (2016). Isotopic characteristics of cryospheric waters in parts of Western Himalayas, India. Environ. Earth Sci. 75:600. doi: 10.1007/s12665-016-5417-8

Raj, R., Chamyal, L. S., Prasad, V., Sharma, A., Tripathi, J. K., and Verma, P. (2015). Holocene climatic fluctuations in the Gujarat Alluvial Plains based on a multiproxy study of the Pariyaj Lake archive, western India. Palaeogeogr. Palaeoclimatol. Palaeoecol. 421, 60-74. doi: 10.1016/j.palaeo.2015.01.004

Ramesh, R., and Sarin, M. M. (1992). Stable isotope study of Ganga (Ganges) river system. J. Hydrol. 139, 49-62. doi: 10.1016/0022-1694(92)90194-Z

Rasmussen, K. L., and Houze, R. A. Jr. (2012). A flash-flooding storm at the steep edge of high terrain: disaster in the Himalayas. Bull. Am. Meteorol. Soc. 93, 1713-1724. doi: 10.1175/BAMS-D-11-00236.1

Raymo, M. E., and Ruddiman, W. F. (1992). Tectonic forcing of Late Cenozoic climate. Nature 359, 117-122. doi: 10.1038/359117a0

Ruddiman, W. F., and Kutzbach, J. E. (1989). Forcing of late Cenozoic northern hemisphere climate by plateau uplift in southern Asia and the American West. J. Geophys. Res. 94, 18409-18427. doi: 10.1029/JD094iD15p 18409 
Sangode, S. J., Phadtare, N. R., Meshram, D. C., Rawat, S., and Suresh, N. (2011). A record of Lake Outburst in the Indus valley of Ladakh Himalaya, India. Curr. Sci. 100, 1712-1718.

Sangode, S. J., Rawat, S., Meshram, D. C., Phadtare, N. R., and Suresh, N. (2013). Integrated mineral magnetic and lithologic studies to delineate dynamic modes of depositional conditions in the Leh valley basin, Ladakh Himalaya, India. J. Geol. Soc. India 82, 107-120. doi: 10.1007/s12594-013-0129-0

Scherler, D., Munack, H., Mey, J., Eugster, P., Wittmann, H., Codilean, A. T., et al. (2014). Ice dams, outburst floods, and glacial incision at the western margin of the Tibetan Plateau: A > 100 ky chronology from the Shyok Valley, Karakoram. Geol. Soc. Am. Bull. 126, 738-758. doi: 10.1130/B30942.1

Schmidt, S., and Nüsser, M. (2017). Changes of High Altitude Glaciers in the transHimalaya of Ladakh over the Past Five Decades (1969-2016). Geosciences 7:27. doi: 10.3390/geosciences 7020027

Schneider, T., Bischo, T., and Haug, G. H. (2014). Migrations and dynamics of the intertropical convergence zone. Nature 513, 45-53. doi: 10.1038/nature13636

Searle, M. P. (1991). Geology and tectonics of the Karakoram Mountains. Hoboken, NJ: John Wiley \& Sons Inc, 358.

Searle, M. P., Pickering, K. T., and Cooper, D. J. W. (1990). Restoration and evolution of the intermontane Indus molasse basin, Ladakh Himalaya, India. Tectonophysics 174, 301-314. doi: 10.1016/0040-1951(90)90327-5

Sekar, B., Rajagopalan, G., and Bhattacharyya, A. (1994). Chemical analysis and 14C dating of a sediment core from Tsokar lake, Ladakh and its implications on climatic changes. Curr. Sci. 67, 36-39.

Shafiq, M. U., Bhat, M. S., Rasool, R., Ahmed, P., Singh, H., and Hassan, H. (2016). Variability of Precipitation regime in Ladakh region of India from 1901-2000. J. Climatol. Weather Forecast. 4:165. doi: 10.4172/2332-2594.1000165

Sharma, A. (2017). "Sample size dependent OSL age: results from Ladakh, India," in Proceedings of the International Conference on Geology: Emerging Methods and Applications (GEM 2017), Kerala, 30.

Sharma, A., Kumar, K., Laskar, A., Singh, S. K., and Mehta, P. (2017). Oxygen, deuterium, and strontium isotope characteristics of the Indus River water system. Geomorphology 284, 5-16. doi: 10.1016/j.geomorph.2016.12.014

Sharma, K. K., Gu, Z., Lal, D., Caffee, M. W., and Southon, J. (1998). Late Quaternary morphometric evolution of Upper Indus valley profile: a cosmogenic radionuclide study of river polished surfaces. Curr. Sci. 4, 366-371.

Shi, Y., Yu, G., Liu, X., Li, B., and Yao, T. (2001). Reconstruction of the 30e40 ka BP enhanced Indian monsoon climate based on geological records from the Tibetan Plateau. Palaeogeogr. Palaeoclimatol. Palaeoecol. 169, 69-83. doi: 10.1016/S0031-0182(01)00216-4

Shukla, U. K., Kotlia, B. S., and Mathur, P. D. (2002). Sedimentation pattern in a trans-Himalayan Quaternary lake at Lamayuru (Ladakh), India. Sediment. Geol. 148, 405-424. doi: 10.1016/S0037-0738(01)00160-9

Singh, I. B., Sahni, A. S. H. O. K., Jain, A. K., Upadhyay, R., Parcha, S. K., Parmar, V., et al. (2015). Post-collision sedimentation in the Indus Basin (Ladakh, India): Implications for the evolution of the northern margin of the Indian Plate. J. Paleontol. Soc. India 60, 97-146.

Singh, S., and Jain, A. K. (2007). Liquefaction and fluidization of lacustrine deposits from Lahaul-Spiti and Ladakh Himalaya: geological evidences of palaeoseismicity along active fault zone. Sediment. Geol. 196, 47-57. doi: 10.1016/j.sedgeo.2006.06.005

Singh, S., Sinha, P., Jain, A. K., Singh, V. N., and Srivastava, L. S. (1975). Preliminary report on the January 19, 1975, Kinnaur earthquake in Himachal Pradesh. Earthquake Eng. Stud. 75, 1-32.
Singh, S. K., Sarin, M. M., and France-Lanord, C. (2005). Chemical erosion in the eastern Himalaya; major ion composition of the Brahmaputra and $813 \mathrm{C}$ of dissolved inorganic carbon. Geochimica et Cosmochimica Acta 69, 3573-3588. doi: 10.1016/j.gca.2005.02.033

Sinha, A. K. (1989). Geology of higher central Himalaya. New York, NY: Wiley, 219. Sinha, R., Smykatz-Kloss, W., Stuben, D., Harrison, S. P., Berner, Z., and Kramar, U. (2006). Late Quaternary palaeoclimate reconstruction from the lacustrine sediments of the Sambhar playa core, Thar Desert margin, India. Palaeogeogr. Palaeoclimatol. Palaeoecol. 233, 252-270. doi: 10.1016/j.palaeo.2005. 09.012

Srivastava, P., Ray, Y., Phartiyal, B., and Sharma, A. (2013). Late PleistoceneHolocene morphosedimentary architecture, Spiti River, arid higher Himalaya. Int. J. Earth Sci. 102, 1967-1984. doi: 10.1007/s00531-013-0871-y

Steck, A., Spring, L., Vannay, J. C., Masson, H., Bucher, H., Stutz, E., et al. (1993). The tectonic evolution of the northwestern Himalaya in eastern Ladakh and Lahul, India. Geol. Soc. Lond. Spec. Publ. 74, 265-276. doi: 10.1144/GSL.SP. 1993.074.01.19

Viviroli, D., Durr, H. H., Messerli, B., Meybeck, M., and Weingartner, R. (2007). Mountains of the world, water towers for humanity: typology, mapping, and global significance. Water Resour. Res. 43, 1-9. doi: 10.1029/2006WR00 5653

Wagner, B., Cremer, H., Hultzsch, N., Gore, D. B., and Melles, M. (2004). Late Pleistocene and Holocene history of Lake Terrasovoje, Amery Oasis, East Antarctica, and its climatic and environmental implications. J. Paleolimnol. 32, 321-339. doi: 10.1007/s10933-004-0143-8

World Clim Res Programme [WCRP] (2009). The World Climate Research Programme Implementation Plan 2010-2015. Jeneva: WCRP.

Wünnemann, B., Demske, D., Tarasov, P., Kotlia, B. S., Reinhardt, C., Bloemendal, J., et al. (2010). Hydrological evolution during the last $15 \mathrm{kyr}$ in the Tso Kar lake basin (Ladakh, India), derived from geomorphological, sedimentological and palynological records. Quat. Sci. Rev. 29, 1138-1155. doi: 10.1016/j.quascirev.2010.02.017

Yin, A. (2006). Cenozoic tectonic evolution of the Himalayan orogen as constrained by along-strike variation of structural geometry, exhumation history, and foreland sedimentation. Earth Sci. Rev. 76, 1-131. doi: 10.1016/j. earscirev.2005.05.004

Zhisheng, A., Guoxiong, W., Jianping, L., Youbin, S., Yimin, L., Weijian, Z., et al. (2015). Global monsoon dynamics and climate change. Annu. Rev. Earth Planet. Sci. 43, 29-77. doi: 10.1146/annurev-earth-060313-054623

Zhou, A., He, Y., Wu, D., Zhang, X., Zhang, C., Liu, Z., et al. (2015). Changes in the Radiocarbon Reservoir Age in Lake Xingyun, Southwestern China during the Holocene. PLoS One 10:e0121532. doi: 10.1371/journal.pone.012 1532

Conflict of Interest Statement: The authors declare that the research was conducted in the absence of any commercial or financial relationships that could be construed as a potential conflict of interest.

Copyright (๑) 2018 Sharma and Phartiyal. This is an open-access article distributed under the terms of the Creative Commons Attribution License (CC BY). The use, distribution or reproduction in other forums is permitted, provided the original author(s) and the copyright owner(s) are credited and that the original publication in this journal is cited, in accordance with accepted academic practice. No use, distribution or reproduction is permitted which does not comply with these terms. 